\title{
Durkheim's herbarium
}

Situating Arnold van Gennep's review of Émile Durkheim's The elementary forms of the religious life

Thomassen, Bjørn

Published in:

HAU: Journal of Ethnographic Theory

DOI:

10.14318/hau7.1.001

Publication date:

2017

Document Version

Publisher's PDF, also known as Version of record

Citation for published version (APA):

Thomassen, B. (2017). Durkheim's herbarium: Situating Arnold van Gennep's review of Émile Durkheim's The elementary forms of the religious life. HAU: Journal of Ethnographic Theory, 7(1), 567-575.

https://doi.org/10.14318/hau7.1.001

\section{General rights}

Copyright and moral rights for the publications made accessible in the public portal are retained by the authors and/or other copyright owners and it is a condition of accessing publications that users recognise and abide by the legal requirements associated with these rights.

- Users may download and print one copy of any publication from the public portal for the purpose of private study or research.

- You may not further distribute the material or use it for any profit-making activity or commercial gain.

- You may freely distribute the URL identifying the publication in the public portal.

\section{Take down policy}

If you believe that this document breaches copyright please contact rucforsk@kb.dk providing details, and we will remove access to the work immediately and investigate your claim. 


\title{
Durkheim's herbarium
}

\section{Situating Arnold van Gennep's review of Émile Durkheim's The elementary forms of the religious life}

\author{
Bjørn Thomassen, Roskilde University
}

This introductory article situates Arnold van Gennep's review of Émile Durkheim's The elementary forms of the religious life. It does so by relating the review to van Gennep's much-neglected endeavor to establish methodological foundations for the emerging social sciences in the early twentieth century, in open contrast to Durkheim and the Durkhemian school of anthropology and sociology. It also contextualizes the review by revisiting earlier publications where van Gennep decisively went up against Durkheim's approach to religion and society. The article finally suggests that Arnold van Gennep must be considered a founding figure of ethnographic theory, of relevance still today.

Keywords: Arnold van Gennep, Émile Durkheim, religion (theory of), ritual, ethnographic theory, history of social science

Having no feel for life, no feel for biology or ethnography, he transforms living phenomena and beings (vivants) into scientifically desiccated plants arranged as in a herbarium.

What could possibly justify a translation and reprint of a review written by Arnold van Gennep more than a century ago? A review, moreover, of one of the most debated books in the history of the social sciences-Durkheim's The elementary forms of the religious life (EFRL from now on)? Has not everything been said that needs to be said? Alas, no.

When Durkheim published EFRL in 1912, it received both acclaim and criticism. In terms of reception, the book went through its own unsurprising but highly problematic "division of labour": sociologists would generally gloss over the long 
and descriptive ethnographic parts on Aboriginal Australian myth and ritual (the main part of the book) and jump straight to the overall conclusions. At this level, it was widely agreed that Durkheim had contributed a decisive statement about the origin and nature of religion, and about society as such. EFRL is without rivalry the most quoted and used work in the sociology of religion ever-and it figures as a core reading in any university course still today.

Anthropologists and area specialists were more critical. Even Radcliffe-Brown, the proto-Durkhemian among English anthropologists, found that the ethnographic parts were based on a series of misinterpretations, and wrote so in a letter to Mauss (Kuper 1988: 177). Yet he still celebrated the theoretical edifice and domesticated Durkheim's functionalism for future generations. With time, the book established itself as the foundational text for both the anthropology and sociology of religion. Subsequent critiques of Durkheim's position (and there are many) have never questioned EFRL's status as a "classic," the mature masterpiece of the founding father of our social sciences.

Arnold van Gennep's review occupies a singular position in these early debates about religion and society. He had himself published on totemism and on the Australian material, and had a detailed knowledge of Durkheim's sources. At this level his critique is categorical. However, the ethnographic weakness cannot be detached from the general view of religion and society that Durkheim presented in EFRL. Indeed, the most crucial aspect of the review concerns the "sociological" part, the general theory. Van Gennep says quite simply that there is no theory whatsoever. What Durkheim presents is nothing but a "metaphysical" abstraction, a "scholastic" thought-experiment, an invention of a desk-scholar. If van Gennep is right, we have for more than a century been discussing a theory which never existed. It is worth contemplating. Van Gennep's review not only forces us to question EFRL's status as a classic. It also raises questions that, far from belonging to the footnotes of intellectual history, relate to foundational questions of the What, How, and Why of ethnographic theory. To appreciate this deeper relevance, it is necessary to briefly contextualize the review, and say something about the man who wrote it

\section{Situating Arnold van Gennep}

Arnold van Gennep (1873-1957) is one of the least recognized and understood anthropologists still today. He became known outside smaller circles of European folklorists only after 1960, when Rites of passage (originally published in 1909) was translated into English. Van Gennep had died three years before, in the midst of general oblivion. Rites of passage is a powerful book, and became an instant success-with half a century of delay. Upon its reading, key figures such as Leach, Needham, and Evans-Pritchard expressed sincere wonder as to why van Gennep had not been held in higher regard within French anthropology. Leach (1968: 522) concluded that van Gennep's approach to ritual had proven much more fertile than that of Durkheim. How could someone write such a book without ever holding a position at a French university? Needham (1967: xi) even called the general disregard of van Gennep "an academic disgrace." Needham had gained some insight into van Gennep's universe, as he translated The semi-scholars into English in 1967. 
No further work of van Gennep has since been translated into English, so Matthew Carey's translation in this issue is the first translation of a van Gennep text in exactly fifty years. The semi-scholars is a prose-style ironic account of academic specialization and the farcical but tragic loss of both commonsense and ultimate purpose in the pursuit of gay science.

Needham understood that the book somehow reflected van Gennep's own experience with institutionalized academia. He also intuited that van Gennep must somehow have been "kept away" from the academic world of Paris, but never ventured further into the issue. Arnold van Gennep is today well known among European folklorists (Belmont [1974] 1979; Senn 1974), but he has remained a puzzle for anthropologists. And sociologists quite simply don't know him.

History commits strange injustices. Van Gennep is one of the most prolific writers and well-read social scientists in modern European intellectual history. His encyclopedic knowledge was second to none. His review activities were amazingly prolific and wide ranging. Between 1905 and 1949 he published 250 review articles just for Mercure de France, the journal where his review of EFRL appeared in January 1913. Since he would typically review three to five books together in each "chronique" for Mercure, we are dealing with more than a thousand books reviewed-in this one journal alone, and he published for many others. In 1908 van Gennep had himself founded La Revue des Etudes Ethnographiques et Sociologiques, in which he would publish regularly while functioning as Directeur and administrator. This journal, albeit short-lived, could well be seen as a potential competitor to L'Année Sociologique, founded by Durkheim in 1898.

Van Gennep reviewed extensively because he had to: it added a bit to his income, which he put together via an array of freelance jobs, never receiving a salaried job in French academia. But he evidently enjoyed it as well, devouring with intense curiosity anything that was brought to his attention. His reviews dealt with literature across the social sciences in at least ten different languages, including French, English, German, Dutch, Italian, Spanish, and a handful of Slavic languages. He consulted all major journals in Europe and America, and contributed to many of them. In an article from 1927, discussing the use of the subconscious in the study of living languages, he started mastering eighteen languages plus a number of their dialects (Belmont [1974] 1979: 7). It was van Gennep who translated some of the most important works into French (including Frazer and Westermarck, not to forget the eighteen volumes of Havelock Ellis' series on sexual psychology). Already in this role of translator and transmitter of European anthropology, folklore, poetry, art, history, and psychology, van Gennep played a nonnegligible role for the French social sciences during the first half of the twentieth century.

Van Gennep was a meticulous but honest reviewer, always approaching the work under review with careful respect. His critical sense was sharp as a knife, but he would maintain an extremely sober and respectful tone when dealing with other people's work. As the reader will probably appreciate, this was hardly the case with van Gennep's review of EFRL. The review is bitingly sarcastic. While sprinkled with gentle doses of humor, van Gennep annihilates Durkheim's entire enterprise. He thereby also debunks the epistemological and methodological foundations of the Durkhemian school. Why this uncompromising tone? To understand the stakes, we need to take a step back and consider van Gennep's relationship to the Durkhemian school. 


\section{Arnold van Gennep and the French social sciences}

In most encyclopedic entries, van Gennep is described as an "outsider" to the inner circles of French academia. This is somewhat true. Van Gennep never got a job offer in French academia. He was born outside France (although he came to France at the age of six with his mother), and as a young man he lived for a longer period in Russian Poland, before moving to Paris to study in 1901. It is also clear that van Gennep possessed a rebellious nature. At the same time, the "outsider story" simply does not add up. Van Gennep was, in his early career, extremely close to the inner circles of French academic life. His critique of Durkheim came from a vision he gained from within. And the critique took shape during the formative years of social science discipline formation.

At the beginning of the century, van Gennep studied sciences religieuses with Léon Marillier at the École Pratique, in close contact with that cohort of young people later to become Durkheim's collaborators, including Marcel Mauss, Henri Hubert, Paul Fauconnet, and many others. Upon Marillier's death in 1901, Mauss became van Gennep's teacher and mentor. In 1903, Mauss proofread and commented upon van Gennep's thesis on taboo and totemism in Madagascar. Van Gennep's interests during the first decade of the century developed alongside those of the Durkheimians, including the classical topics of totemism, taboo, the origins and nature of religion, magic, classification systems, and the relationship between myth and ritual. The relation to Mauss seems to have been especially important, even profound. They were contemporaries, and their positions converged in important ways (for more detail, see Thomassen 2016, on which this and the following section draws). In the preface to his first book, Tabou et totémisme à Madagascar: Étude descriptive et théorique from 1904, van Gennep reserves the final thanks to "mon ami Marcel Mauss" (van Gennep 1904: 2).

In 1906 van Gennep published his second book, Mythes et légendes d'Australie, in which he chose to openly expose the problems with Durkheim's work. This is important to know: his 1913 review of EFRL was not a sudden impulse, but the culmination of a critical engagement that had started a decade before. Van Gennep's discussion of Durkheim in his 1906 book goes straight to the heart of the latter's position. Before 1906, Durkheim and Mauss had written several essays on religion referring to the Australian material. Van Gennep was not convinced. His critique started off from an issue which was then the object of endless debate: whether it was possible to establish which descent system was the "original one." Referring to the Australian material, Durkheim had argued that matrilineal descent could be considered the original mode of social organization, only that over time it had been replaced by patrilineal descent. Van Gennep argued back that in many Australian societies parallel systems coexist, and that a social scientist should refrain from speculating about "origins" in the absence of empirical evidence. He thereby uncovered the evolutionist stance that lurks behind Durkheim's explanatory apparatus. Durkheim had wanted to cut off historical explanations from sociological science, but the moment he set out to theorize himself, he plunged into evolutionist speculation.

Van Gennep therefore questions the adopted analytical procedure by which Durkheim posits the Arunta at a certain level or stage of "development," allowing 
him an analytical short-cut to the question of "origins." Whenever Durkheim recognizes a change, over time, or between groups (in kinship affiliations, for example), he systematically prevents any real account of such a transformation, relegating it simply to the "general needs of society" (van Gennep 1906: xxv). Durkheim presents no grounding epistemology to tell us what such a "society" is to be able to "have" such needs. Durkheim, says van Gennep, operates a peculiar kind of "métaphysique sociologique" (ibid.: xxiv). Positing a "metaphysical abstraction" at the core of his argument, he then artificially "animates" it (ibid.: xxv) by manipulating ethnographic data, and by granting "society" explanatory powers without ever accounting for the very nature of that "society" (the parallels to Gabriel Tarde's earlier critiques of Durkheim are evident; see Thomassen 2012). As van Gennep says, rather provocatively, this means to resolve a problem without having even managed to pose it as a problem (1906: xxv).

On those same fatal pages, van Gennep took one step further in his critique, pointing towards the dangerous political implications of Durkheim's categorical collectivism:

We have seen how Mr. Durkheim explains social modifications by the "needs of society" without indicating either the why or the where of those needs, and without justifying how exactly a "society," however small, may have "needs" in the first place. It is by an identical process of animation that they speak to us of "the call of the fatherland," or "the voice of the race." Mr. Durkheim anthropomorphizes, even if this is what he pretends to defend himself from. (1906: xxxv, emphasis and inverted commas in the original, my translation)

What a foolishly honest/honestly foolish thing to write in 1906! According to van Gennep, Durkheim's sociology was not just flawed at the theoretical level; the entire epistemology onto which it built bore resemblances to other and much more serious political essentialisms that were showing their ugly face. Durkheim answered van Gennep's critique with absolute silence; but he was evidently aware of it-and there can be no doubt that he discussed it with Mauss.

\section{Rites of passage}

In 1909 van Gennep published Rites de passage. This was a crucial moment in his life, as the writing of the book coincided with his decision in 1908 to quit his job at the Ministry of Agriculture (where he had been head of translations) and dedicate himself wholeheartedly to writing and translating. Rites de passage was van Gennep's most important book, resulting, in his own words, from nothing less than an "inner illumination." It provided him with a conceptual frame that guided him for the rest of his life.

It was Mauss (1910) who reviewed Rites de passage in L'Année, although Durkheim might have had some say as well. Mauss' review was very negative, perhaps unsurprisingly after van Gennep's attack on Durkheim in 1906. It was also a very unfair review, as it distorted the aims and intentions behind the book, showing no appreciation of the conceptual advance it actually presented. Van Gennep, 
however, was determined to carry forward his project. In 1910 he published La formation des légendes, his seventh book. It was followed up by two books in 1911 (one of which was later translated as The semi-scholars). Van Gennep had by then become deeply engaged with general epistemological and methodological issues. Prior to World War I he published a series of programmatic articles in which he started to formulate a methodological platform for the social sciences-an approach which he baptized as a "biological sociology," and which differed from the Durkheimian school on all significant accounts.

In his review of EFRL, van Gennep makes reference to Durkheim's lack of a sense of "biology" This is crucial, but we can only appreciate this comment if we understand that van Gennep's insistence on biology was not an allusion to the authority and objectivity of natural science, but instead a stress on the importance of direct observation, and systematic gathering of data, leading, step by step, to theory building. Van Gennep wanted social scientists to deal with what he called living facts ("faits naissants," e.g., facts in their "emergence") rather than dead and abstract social facts, "external" to the individual, as Durkheim would have it. This is the pivotal contrast that animates the 1913 review. Van Gennep is not exposing just this or that aspect of Durkheim's approach. He is saying that Durkheim's social science has lost sight of human beings. EFRL represented a diametrical opposite to his own attempt to establish anthropology as a life science.

Despite his productivity, van Gennep never passed the threshold into French academia. This certainly had a lot to do with his critique of Durkheim. Following failed candidatures at the Collège de France in 1907, 1909, and 1911, he decided to go abroad. In 1912 he was offered the first (and only) academic position he ever held, as chair in "Swiss ethnography" at the University of Neuchâtel. It was Henri Junod who made it possible. Junod had read Rites de passage and was deeply impressed by it. When EFRL was published, van Gennep was almost an outcast in French academia, already on the move to Switzerland, where he was about to set up his own school of anthropology.

In Rites of passage van Gennep had argued for the centrality of ritual and ritual passages toward an energetic understanding of religious ritual and social processes. He had proposed a universal classification of rites. He had published a book on Australian myth and one on totemism. These should have been central discussions for anyone writing a book about such matters in 1912. Durkheim, however, disregarded van Gennep's contributions altogether-on purpose, as van Gennep cannot help but remark in his review. He had little reason to be diplomatic.

\section{Out of Durkheim's herbarium, into the life sciences}

So why does it all matter? It matters because van Gennep's review of EFRL is not only one of the most radical but perhaps also the very first of such critiques of Durkheim's approach to society and religion-yet even critics of Durkheim have so far neglected it. Nobody then, and nobody since, would have been so uniquely positioned to assess the work in question. The critique has to be taken seriously.

It matters because the review in question does not only throw critical light on the Durkhemian project; it equally throws light back on the life and much-neglected 
work of Arnold van Gennep. The review is not only about what van Gennep was against; it opens a window onto what he was struggling for. "Publish or perish," the slogan goes, but it does not apply to van Gennep, who did indeed publish, and more than almost any social scientist in the twentieth century. And yet he almost nearly perished.

Van Gennep was not just a prolific reader and writer. He had a project, and a larger vision of the social sciences that he tried to build up in the early decades of the twentieth century. Course syllabi on religion today often insert an excerpt from Rites of passage. In today's standard approach, van Gennep is discussed as a supplement to Durkheim's theory of ritual and religion: van Gennep offered a useful terminology for the study of ritual passages, whereas it was Durkheim and others who provided a theoretical framework. Van Gennep would have been seriously uneasy seeing his classification of rites represented as a supplement-or, worse, a parenthesis-to Durkheim's sociology of religion. His entire work was an effort to overcome what he saw as the most serious defects of Durkhemian sociology. I am aware that Durkheim's EFRL will stay on our reading lists for some time to come. But now that van Gennep's review is finally available in English, we could at least start adding it to those reading lists-making it clear to ourselves and our students that his contribution to the study of religion and society was not an addition to Durkheim's, but a genuine alternative.

It matters, finally, because van Gennep's vision for the social sciences was intimately related to the aim of this Maussian journal to inspire ethnographic theorization. While HAU takes its name from Mauss' spirit of the gift, this "spirit" can in fact be traced back to van Gennep. In Rites of passage Van Gennep had largely anticipated Mauss' most salient observations concerning gift giving. Chapter 3 in Rites of passage is almost entirely dedicated to ritualistic exchange of words, gestures, services, goods, slaves, and wives: exactly the aspects of exchange that Mauss systematically took up in his essay on the gift, and which Lévi-Strauss used as platform for his exchange theory. Certain "gifts" are obligatorily given, said van Gennep: the circulation of goods and objects serves to create continuous social bonds ([1909] 1960: 31). Gift giving is the "confirmation of a bond," and "to accept a gift is to be bound to the giver" (ibid.: 29). Van Gennep then discusses, among others, the potlatch as one peculiar example, as he discusses gift-giving practices among warrior groups as a peace-instituting act; he further notes how incorporation rites are often tied to military, sexual, and political rights (ibid.: 35). This crucial conceptual discussion is entitled "Individuals and groups," which precedes the six following chapters, which each deal with a cross-cultural examination of ritual passages as they pertain to the life cycle, from pregnancy to death. Van Gennep anticipated Mauss' insight that gift giving must be seen as a foundational principle at play in ritual phenomena, weaving together individuals and groups-neither of which can or should be reduced to each other.

Common wisdom has for a century catalogued van Gennep as a talented ethnographer and folklorist, but ultimately an undisciplined figure lingering at the margins of the social sciences, and unfortunately without a theory. In Routledge's Key thinkers, Karady (1987: 255) characteristically claimed that van Gennep's approach was "essentially empirical with limited theoretical underpinning." It is high time we turn conventional wisdom on its head. Arnold van Gennep was a daring 
thinker across disciplines exactly because he was an eminent ethnographer, a theorist with a passion for living facts in all their spirited materiality. He clearly must be ranked among the founding figures of ethnographic theory.

\section{Contextualisation du compte-rendu critique de van Gennep au sujet des Formes élémentaires de la vie religieuse d'Émile Durkheim}

Résumé : Cet article d'introduction contextualise le compte-rendu critique rédigé par van Gennep au sujet de l'ouvrage d'Émile Durkheim Les Formes élémentaires de la vie religieuse. Larticle met en rapport ce compte-rendu et le projet bien souvent négligé qu'avait van Gennep d'établir les fondements méthodologiques des sciences sociales balbutiantes au début du 20e siècle ; un projet qui contrastait fortement avec l'école Durkheimienne de sociologie et d'anthropologie. Le compte-rendu est également placé en relation avec des publications plus anciennes de van Gennep où ils soppose explicitement à l'approche qu'adopte Durkheim dans l'étude de la religion et de la société. Enfin, cet article suggère qu'Arnold van Gennep devrait être considéré comme un fondateur toujours d’actualité de la théorie ethnographique.

\section{References}

Belmont, Nicole. (1974) 1979. Arnold van Gennep: The creator of French ethnography. Chicago: University of Chicago Press.

Karady, Victor. 1987. “Arnold van Gennep.” In Key thinkers, past and present, edited by Jessica Kuper, 255-56. London: Routledge \& Kegan Paul.

Kuper, Adam. 1988. The invention of primitive society. London: Routledge.

Leach, Edmund 1968. "Ritual." In International encyclopedia of the social sciences, Vol. 13, edited by David Sills, 520-26. New York: Macmillan.

Mauss, Marcel. 1910. “[Review of Van Gennep’s Rites de passage].” L’Année Sociologique 11: 200-202. (Reprinted in CEuvres, I, : 553-55. Paris: Minuit, 1968.)

Needham, Rodney. 1967. "Introduction." In The semi-scholars, Arnold van Gennep, ix-xx. Translated by Rodney Needham. London: Routledge.

Senn, Harry A. 1974. "Arnold van Gennep: Structuralist and apologist for the study of folklore in France." Folklore 85: 229-43.

Thomassen Bjørn. 2012. "Durkheim between Gabriel Tarde and Arnold van Gennep: Founding moments of sociology and anthropology." Social Anthropology 20: 231-49.

—. 2016. "The hidden battle that shaped the history of sociology: Arnold van Gennep contra Émile Durkheim.” Journal of Classical Sociology 16: 173-95.

van Gennep, Arnold. 1904. Tabou et totémisme à Madagascar: Éétude descriptive et théorique. Paris: Leroux.

_.1906. Mythes et légendes d'Australie: Études d'ethnographie et de sociologie. Paris: E. Guilmoto. 
(1909) 1960. The rites of passage. Translated by Monika B. Vizedom and Gabrielle L. Caffee. London: Routledge \& Kegan Paul.

Arnold van Gennep (1873-1957) was a French folklorist best known for his 1909 book, Rites of passage.

Bjørn Thomassen is Associate Professor at the Department of Social Sciences and Business, Roskilde University. His work engages anthropological and social theory applied to a variety of social fields, including the study of political revolutions and social mobilization. He publishes in journals across the social sciences. Recent books include Italian modernities (coauthored with Rosario Forlenza; Palgrave, 2016); Breaking boundaries: Varieties of liminality (edited with Agnes Horvath and Harald Wydra; Berghahn, 2015); Liminality and the modern: Living through the in-between (Ashgate, 2014); and Global Rome: Changing faces of the Eternal City (edited with Isabella Clough Marinaro; Indiana University Press, 2014).

Bjørn THOMASSEN Department of Social Sciences and Business

Universitetsvej 1

Building 23.1 4000 Roskilde

Denmark

bthomas@ruc.dk 